FIU Law Review

Spring 2008

\title{
Culture Shock: Expanding the Current Federal Law Against Female Genital Mutilation
}

Vanessa Ortiz

Follow this and additional works at: https://ecollections.law.fiu.edu/lawreview

Part of the Other Law Commons

Online ISSN: 2643-7759

\section{Recommended Citation}

Vanessa Ortiz, Culture Shock: Expanding the Current Federal Law Against Female Genital Mutilation, 3 FIU L. Rev. 423 (2008).

DOI: https://dx.doi.org/10.25148/lawrev.3.2.10

This Comment is brought to you for free and open access by eCollections. It has been accepted for inclusion in FIU Law Review by an authorized editor of eCollections. For more information, please contact lisdavis@fiu.edu. 


\title{
Comments
}

\section{Culture Shock: Expanding the Current Federal Law Against Female Genital Mutilation}

\author{
Vanessa Ortiz*
}

I. Introduction.............................................................................424

II. Types of Female Genital Mutilation and their Effects ....................426

A. Types of Female Genital Mutilation .........................................427

B. The Consequences of Female Genital Mutilation.......................427

1. Physical Implications ..................................................428

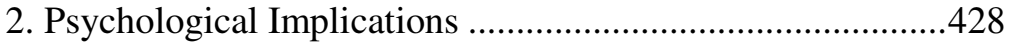

3. Social Inequality..........................................................429

C. Cultural Beliefs Surrounding the Practice ..............................431

1. Societal Traditions.............................................................441

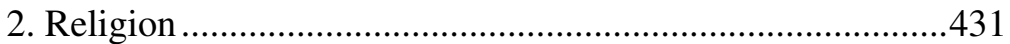

3. Thwarting Promiscuity ...................................................432

4. Hygiene and Aesthetics ................................................432

III. The Criminalization of Female Genital Mutilation .......................433

A. Female Genital Mutilation in the United States.........................433

B. Illegal Immigration Reform and Immigrant Responsibility

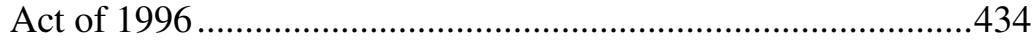

C. Female Genital Mutilation in the Courtroom ............................436

1. Abrogating the Cultural Defense: A Step in the Right

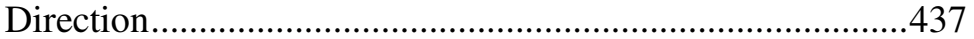

D. Congress' Power to outlaw Female Genital Mutilation..............439

1. The Commerce Clause Analysis........................................439

2. The First Amendment Analysis .........................................441

* Juris Doctorate, Florida International University College of Law; Bachelor of Arts, Florida International University. I would like to thank Professor David Walter for his advice and support throughout the completion of this project. I would also like to thank my family and friends for their unwavering love and support. Most importantly, I would like to thank my parents, Lazaro and Mariana Morales, for being my biggest fans. 
a. The Establishment Clause ..............................................442

b. The Free Exercise Clause .............................................443

3. The Right to Self-Determination ......................................446

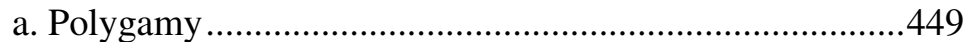

b. Suicide ......................................................................449

IV. Strengthening the U.S. Voice Against Female Genital Mutilation ..450

A. Differing International Theories: Which Should Apply?...........450

1. Cultural Relativism ........................................................451

2. Universalism ...............................................................451

B. International Resolutions Against Female Genital Mutilation....453

C. Learning from the International Community ..........................456

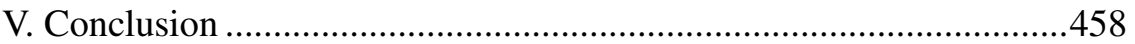

\section{INTRODUCTION}

A seventeen-year-old girl, stripped naked, sits on a low chair. Several women grab the girl and pin her body down as they open her legs wide. The hood of the girl's clitoris is then punctured and sliced open with an unwashed, un-sanitized, sharply filed kitchen knife. They then begin to cut out the girl's organ. As another woman wipes off the blood that gushes from the girl's body with a dirty rag, the girl's organ is ripped out by digging a hole the size of the clitoris with the operator's sharp fingernail and disconnecting the organ. The girl, who is held down by the women helpers, sobs and screams in excruciating pain.

The seventeen-year-old girl's clitoris is entirely ripped out as the operator cuts into the bone with her sharp knife. Then, the girl's remaining flesh is removed along with any remainder of the clitoris by digging with the operator's fingernail, as blood gushes like a fountain from the girl's organ. The girl's inner lips (labia minora) are cut off by the dirty blade. Once the lips are cut off, the skin from inside the girl's large lips (labia majora) is scraped off with the rapid motion of the operator's knife.

After the scraping of the skin is completed, the girl's bleeding, large lips are stitched together with long acacia thorns. The seventeen-year-old girl is left with an opening no larger then the head of a matchstick to allow for the passing of urine and the girl's menstrual flow. The honor of the girl's family depends on the size of the opening - the smaller the opening, the greater the value of the girl and the higher the bride-price.

The girl's legs are then tied together, from the knee to the waist, with goat skin to immobilize her thighs. This bandage is left in place for two weeks. The girl is forced to remain lying on a mat for the entire two-week period, while the blood and other secretions remain in her bandages, often causing infection and disease. After the two-week period, the bandages are removed and the girl is released from her temporary confinement. Her va- 
gina is now closed and will remain this way until marriage to preserve her purity.

This is a brief description ${ }^{1}$ of female genital mutilation ${ }^{2}$ as it is practiced in Somalia, where all girls must undergo this procedure in order to be married. ${ }^{3}$ Female genital mutilation is a cultural and religious practice that has been performed on approximately 80-200 million women around the world. ${ }^{4}$ The practice is performed on women in over 40 countries. "Most of them live in [twenty-eight] African countries, a few in the Middle East and Asian countries, and increasingly in Europe, Canada, Australia, New Zealand and the United States of America." ${ }^{\circ}$ Female genital mutilation occurs at a rate of approximately 6,000 girls per day. ${ }^{7}$ Female genital mutilation was legally practiced in the United States from the late nineteenth century until about 1937. ${ }^{8}$ As new immigrants continue to arrive in the United States, female genital mutilation is becoming common again and has thus captured much attention and debate.' The United States criminalizes this practice under federal law when it is performed on a seventeen-year-old

1 Karen Hughes, The Criminalization of Female Genital Mutilation in the United States, 4 J.L. \& POL'Y 321, 322-23 (1995).

2 Female genital mutilation is also known as female circumcision, but for the purposes of consistency, this Comment will use the term "female genital mutilation." "The male equivalent to female genital mutilation would be the cutting and/or amputation of the penis and its surrounding tissues." Robbie D. Steele, Note, Silencing the Deadly Ritual: Efforts to End Female Genital Mutilation, 9 GEO. IMMigr. L.J. 105, 106 (1995) (quoting STAFF OF REP. PATRICIA SCHROEDER, 104TH CONG., 1ST SESS., Summary of Federal and State Legislation on Female Genital Mutilation (1995)).

3 Fran P. Hosken, The Hosken Report 25 (3d ed. 1982). Female genital mutilation is performed on young girls during infancy or puberty. Cassandra Terhune, Comment, Cultural and Religious Defenses to Child Abuse and Neglect, 14 J. AM. ACAD. MATRIM. L. 152, 158 (1997). It may also be performed before marriage or during a woman's first pregnancy. Id.; see also Naomi Mendelsohn, Note, At the Crossroads: The Case For and Against a Cultural Defense to Female Genital Mutilation, 56 RUTGERS L. REV. 1011, 1012 (2004).

4 Day One: Scarred for Life (ABC television broadcast, Sept. 20, 1993) (transcript available in LEXIS, Nexis Library); Terhune, supra note 3, at 156. Every year two million girls are at risk of being subjected to female genital mutilation, and 135 million women worldwide have undergone the procedure. Amnesty International, La Mutilacion Femenina y los Derechos Humanos: Infibulacion, Excision, y Otras Practicas Cruentas de Iniciacion 20, 23 (1998) [hereinafter Amesty International].

5 Hosken, supra note 3, at 25; Khadijah F. Sharif, Female Genital Mutilation: What Does the New Federal Law Really Mean?, 24 Fordham Urb. L.J. 409, 412 (1997); Robert A. Myers et al., Circumcision: Its Nature and Practice Among Some Ethnic Groups In Southern Nigeria, 21 Soc. SCI. MED. 581, 584 (1995).

6 Jaimee K. Wellerstein, Comment, In the Name of Tradition: Eradicating the Harmful Practice of Female Genital Mutilation, 22 LOY. L.A. INT'L \& COMP. L. REV. 99, 100 (1999) (citing WorLD Health Organization, Female Genital Mutilation: Information Pack, http://www.who.int/frhwhd/FGM/infopack/English/fgm_infopack.htm (last visited Sept. 2, 1999)).

7 Mendelsohn, supra note 3, at 1014.

8 Ben Barker-Benfield, Sexual Surgery in Late-Nineteenth-Century America, 5 InT'L J. HEALTH SERV. 279, 285 (1975).

9 Lori Ann Larson, Note, Female Genital Mutilation in the United States: Child Abuse or Constitutional Freedom?, 17 WOMEN's RTS. L. REP. 237, 237-38 (1996). 
girl, however, U.S. law does not afford the same protection to an eighteenyear-old girl. ${ }^{10}$

This Comment proposes that the legislation currently enacted to criminalize female genital mutilation be expanded to include adult women in addition to children. Part II of this Comment summarizes the history of female genital mutilation. ${ }^{11}$ It sets out the consequences associated with the procedure and the beliefs surrounding the practice. ${ }^{12}$ Part III analyzes the current law in the United States criminalizing female genital mutilation, ${ }^{13}$ and it analyzes the constitutionality of the law under the Commerce Clause and the First Amendment. ${ }^{14}$ It also analyzes the law under the right to selfdetermination and compares the practice to other cultural and religious practices that are currently prohibited in the United States. ${ }^{15}$ Finally, Part IV discusses the criminalization of female genital mutilation under international law ${ }^{16}$ and proposes that the United States evaluate the international provisions prohibiting female genital mutilation and expand the law in the United States to ban the practice against adult women. ${ }^{17}$

\section{TyPES OF FEMALE GENITAL MUTILATION AND THEIR EFFECTS}

Female genital mutilation began in fifth century B.C. ${ }^{18}$ no consensus as to whether the practice began in one geographic area and then spread, or whether it was created by different ethnic groups in different areas at different times. ${ }^{19}$ Section A and B explain the different types of female genital mutilation and the consequences, both physical and psychological, associated with the practice. $^{20}$ Finally, Section $\mathrm{C}$ explores the cultural beliefs surrounding the practice and provides a brief overview of its development in the United States. ${ }^{21}$

10 The Federal Female Genital Mutilation Act, 18 U.S.C. $§ 116$ (1996); Illegal Immigration Reform and Immigrant Responsibility Act of 1996, Pub. L. 104-208, § 645, 110 Stat. 3009-546 (1996).

See infra Part II.

See infra Part II.B.

See infra Part III.

See infra Part III.D.

See infra Part III.D.3.

See infra Part IV.

See infra Part IV.C.

18 Hughes, supra note 1, at 330 (citing Hanny Lightfoot-Klein, Prinsoners OF RITUAL: AN OdYSSEY INTO FEMALE GENITAL CIRCUMCISION IN AFRICA 27 (1989)).

19 Hosken, supra note 3, at 51.

20 See infra Parts II.A -B.

21 See infra II.C. 


\section{A. Types of Female Genital Mutilation}

There are four types of female genital mutilation. With the least severe form, ritual circumcision, the clitoris is "nicked." 22 The second form, sunna circumcision, ${ }^{23}$ involves the removal of the hood (prepuce) of the clitoris. $^{24}$ The third and most typical form is excision, also known as clitoridectomy. ${ }^{25}$ This type requires the removal of the clitoris and some or all of the labia minora.

Finally, the most severe type of female genital mutilation is infibulation. $^{27}$ This procedure requires the cutting of the clitoris, labia minora, and labia majora, ${ }^{28}$ and the sewing together of both sides of the vulva, leaving only a tiny opening for purposes of urination and menstruation. ${ }^{29}$ Once the procedure is completed, the girl's legs are bound together. ${ }^{30}$ This procedure is usually performed in unsanitary conditions ${ }^{31}$ without anesthetics. ${ }^{32}$ The practitioners use razor blades, iron knives, pieces of cut glass, sharp stones, hot rocks, or other home made tools to perform the procedure. ${ }^{33}$ The results of this non-hygienic procedure have a devastating effect on the girl's or adult woman's health and psyche at the moment that it is performed and in the years to follow.

\section{B. The Consequences of Female Genital Mutilation}

Female genital mutilation has a variety of serious implications associated with it. Section one discusses the physical consequences caused by female genital mutilation. ${ }^{34}$ Section two discusses the psychological consequences associated with female genital mutilation. ${ }^{35}$ Finally, section three explains the social inequality associated with the practice. ${ }^{36}$

\footnotetext{
22 Helen Signy, Australia: The Unkindest Cut, Sydney Morning Herald, Feb. 26, 1994.

23 In Muslim countries, the word "sunna" means tradition. EFUA DORKENOO \& SCILlA Elworthy, Female Genital Mutilation: Proposals For Change 7-8 (3d ed. 1992).

24 G.H. Sayed et al., The Practice of Female Genital Mutilation in Upper Egypt, 55 INT. J. GYNECOLOGY \& OBSTETRIC 285, 286 (1996).

25 Signy, supra note 22.

26 Sayed, supra note 24, at 286.

27 Maggie Garb, U.S. Doctors Seeing “Circumcised” Female Immigrants, 33 AM. MED. NEws 3 (1990); see supra text preceding footnote 1 for a more thorough description of this procedure.

28 Sayed, supra note 24, at 286.

29 Garb, supra note 27, at 3.

30 See What's Culture Got to do With It? Excising the Harmful Tradition of Female Circumcision, Note, 106 HARV. L. REV. 1944, 1946 (1993) [hereinafter What's Culture Got to do With It?]; Larson, supra note 9 , at 239 .

31 Terhune, supra note 3, at 158; Leslie R. Walker et al., Female Circumcision: A Report of Four Adolescents, 17 J. OF AdOLESCENT HEALTH 128, 130 (1995).

32 What's Culture Got to do With It?, supra note 30, at 1946.

33 Id. at 1946.

34 See infra Part II.B.1

35 See infra Part II.B.2.

36 See infra Part II.B.3.
} 


\section{Physical Implications}

The practice of female genital mutilation includes serious physical implications for the subjected female. The immediate consequences include pain, hemorrhage, shock, retention of urine and menstrual discharge, tetanus, fever, and genital infections. ${ }^{37}$ There is also a possibility of death if a major blood vessel is accidentally ruptured during the procedure and medical assistance is not received in time.

The procedure also includes post-operative physical effects that may develop later during the woman's life. Such complications include urinary tract infections, keloid formation, cysts, reproductive tract infections that may lead to infertility, difficulty and pain during intercourse, ${ }^{39}$ tetanus and septicemia from unsterile instruments, infection, ${ }^{40}$ and bleeding of adjacent organs. ${ }^{41}$ In addition to these physical effects on the woman, female genital mutilation also affects the woman's birthing process. ${ }^{42}$ Female genital mutilation causes added difficulty and pain during labor. ${ }^{43}$ In addition, there is also a risk that the labor will result in hemorrhaging, tearing of the perineal tissue, and possibly the prolapsing of the uterus. ${ }^{44}$ There are also health risks to the infant such as brain damage from a lack of oxygen during delivery and even the risk of being stillborn. ${ }^{45}$

\section{Psychological Implications}

There are many psychological consequences associated with female genital mutilation. However, these psychological effects may be difficult to determine because of the acceptance of this procedure as a cultural norm. ${ }^{46}$

37 What's Culture Got to do With It?, supra note 30, at 1946; see Dorkenoo, supra note 23. Female genital mutilation survivors may experience dysuria (painful urination) and dysmenorrhoea (painful menstruation) due to pelvic congestion. What's Culture Got to do With It?, supra note 30, at 1945.

38 What's Culture Got to do With It?, supra note 30, at 1946.

39 Id. at 1947; Robin Cerny Smith, Female Circumcision: Bringing Women's Perspectives into the International Debate, 65 S. CAL. L. REv. 2449, n.363 (1992); Efua Dorkenoo, Combating Female Genital Mutilation: An Agenda For the Next Decade, 49 World Health Stat Q 142, 143 (1996). Studies have shown that infibulated women must be cut open to permit insertion of the penis. Smith, supra note 39 , at n.363.

40 Anna Funder, De Minimus Non Curat Lex: The Clitoris, Culture and the Law, 3 TRANSNAT'L L. \& CONTEMP. PROBS. 417, 436 (FALl 1993). In the case of infibulated children, the excrement stays trapped in the bandages that bind her legs together during the immobility period, thus causing severe infection. Larson, supra note 9, at 239.

41 Funder, supra note 40, at 436. Some studies have shown that the repeated use of the same unsterilized tool during multiple operations increases the probability of HIV infection. Isabel Coello, Female Genital Mutilation: Marked By Tradition, 7 CARDOZO J. INT'L \& COMP. L. 213, 216 (1999).

42 What's Culture Got to do With It?, supra note 30, at 1947.

43 Id.

44 Id.

45 Id.

46 Nahid Toubia, Female Circumcision as a Public Health Issue, 331 NEw ENG. J. MED. 712, 714 (1994). 
Even so, many women may suffer pre- and post-operative anxiety due to the fear, pain, and shock of the actual procedure. ${ }^{47}$ There are also feelings of betrayal that may arise when a young girl is forced to undergo the procedure by her mother or other family members. ${ }^{48}$ Female genital mutilation also produces psychological effects such as anxiety and melancholy. ${ }^{49}$ The procedure is also associated with depression, hallucinations, psychosis, and an inability to express fear. ${ }^{50}$ Some studies have shown that the practice of female genital mutilation interferes with the woman's sexuality and obstructs the development of the woman's sexual identity. ${ }^{51}$ Furthermore, the procedure may cause permanent psychological damage and deprive girls and women of practicing societies from deciding how their bodies will look and feel.

\section{Social Inequality}

Female genital mutilation not only affects the women who undergo it, but society as a whole. Cultures that practice female genital mutilation view women as inferior to men. ${ }^{52}$ The women in these cultures have no political voice and are dependent on men due to their lack of education. ${ }^{53}$ This particular view not only mentally reinforces the practice, it mentally subjugates women as a whole. ${ }^{54}$

Female genital mutilation shows an attempt to confer an inferior status on women by branding them with this mark[,] which diminishes them and is a constant reminder to them that they are only women, inferior to men, that they do not even have any rights over their own bodies or fulfilment [sic] either bodily or personal . . . . As we can view male circumcision as a measure of hygiene, we can only see excision as a measure of inferiorization. ${ }^{55}$

Practicing cultures require that girls and adult women undergo female genital mutilation to be socially accepted. ${ }^{56}$ The underlying purpose for the practice is to dominate women by controlling their sexuality and reproduc-

\footnotetext{
What's Culture Got to do With It?, supra note 30, at 1948.

Id.

Funder, supra note 40, at 436

Dorkeno, supra note 23, at 143.

Funder, supra note 40, at 436.

2 See Wellerstein, supra note 6, at 110; Joanne A. Liu, When Law and Culture Clash: Female Genital Mutilation, a Traditional Practice Gaining Recognition as a Global Concern, 11 N.Y. INT'L L.

53 Liu, supra note 52 , at 84

54 Wellerstein, supra note 6, at 111.

55 Coello, supra note 41, at 213 (citing Amnesty International, supra note 4, at 50).

56 Larson, supra note 9, at 239.
} REV. 71,84 (1998). 
tive functions. ${ }^{57}$ This only serves to reinforce the oppression faced by women. ${ }^{58}$ The practice fosters the desire of male-dominated societies to control women by excising their sexuality. ${ }^{59}$ This mandate deprives women of those societies from deciding how their bodies will look and feel. ${ }^{60} \mathrm{Fe}-$ male genital mutilation denies adult women the freedom to possess and control their bodily organs. ${ }^{61}$ The act of removing all or part of the female genitalia deprives young girls and adult women of fundamental female qualities. $^{62}$ It robs women of the chance to be seen as equivalent to males because they are required to remove their body parts to be "beautiful" or socially acceptable.

It also denies women their right to social equality:

It is not that we have to claim that women are equal to men in the sense that they are the same as men; rather, we have to claim that the feminine sex is of equivalent value to the masculine sex, in the name of women's equal personhood before the law. ${ }^{64}$

If women are to be seen as equivalent to males then it is critical that the woman's body be valued in its natural state, without alterations or removal of vital sexual organs that serve to define and preserve the woman's femininity. ${ }^{65}$ Forcing women to remove or mutilate their vital sex organs to be considered socially acceptable conflicts with the notion of equality and, therefore, denies women the right to be seen as having equal worth to men. ${ }^{66}$ Thus, banning female genital mutilation is crucial for women to achieve social equality.

57 Coello, supra note 41, at 215.

58 Wellerstein, supra note 6, at 111 (citing Fran P. HoSKEn, THE HOSKEN REPORT: GENITAL AND SeXual Mutilation of Females 33 (4th rev. ed. 1994)).

59 Liu, supra note 52 , at 85.

60 See id.

61 See id.

62 Id.

63 Larson, supra note 9, at 239

64 Drucilla Cornell, The Imaginary Domain: Abortion, Pornography, and SeXual HARASSMENT 19 (1995). There are three conditions that are required for women to have equal opportunity to transform themselves into "individuated beings who can participate in public and political life as equal citizens." Id.

These conditions are: (1) bodily integrity, (2) access to symbolic forms sufficient to achieve linguistic skills allowing for the differentiation of oneself from others, and (3) the protection of the "imaginary domain," which is the psychological space necessary for an individual to define herself, without having another's (i.e., a man's) imaginary imposed on her. Id. According to Cornell's structure, female genital mutilation would violate all three conditions necessary for the woman to achieve equal personhood by robbing women of their bodily integrity and, therefore, denying them the chance to identify themselves as an individual without having societal ideas of how women's bodies should look forced upon them. Id.

65 Larson, supra note 9, at 239-40.

$66 I d$. at 240. 


\section{Cultural Beliefs Surrounding the Practice}

There are several different cultural beliefs surrounding the practice of female genital mutilation. Section one discusses the traditional aspects surrounding the practice. ${ }^{67}$ Section two discusses the religious beliefs surrounding the practice. ${ }^{68}$ Section three discusses the belief that female genital mutilation thwarts promiscuity. ${ }^{69}$ Finally, section four discusses the hygiene and aesthetic beliefs involved. ${ }^{70}$

\section{Societal Traditions}

Female genital mutilation is considered a traditional ritual in some cultures. $^{71}$ Tradition, "the reluctance to break with age-old practices that symbolize the shared heritage of a particular ethnic group," 72 is the most frequent reason that diverse ethnic groups continue to perform the painful practice. $^{73}$ Elderly women in the various communities insist on the continuance of the tradition. ${ }^{74}$ In some societies, female genital mutilation is like a rite of passage. ${ }^{75}$ It is the traditional ritual that grants full social acceptability and integration into the community among females. ${ }^{76}$ Identifying with one's heritage and being recognized as a member of one's ethnic group is important to most people. For many young girls and women, the ritual of female genital mutilation satisfies this need "to belong" and guarantees that they will not be excluded. ${ }^{77}$ Supporters of the practice claim that "this is what our culture demands. It was handed over to us by our forefathers. We cannot afford not to circumcise our women."

\section{Religion}

Another justification for the practice of female genital mutilation is religious belief. ${ }^{79}$ The religious argument revolves around the idea that modesty and virginity are high virtues that are advised by the Bible and the Ko-

\footnotetext{
See infra text accompanying notes $72-79$.

See infra text accompanying notes $80-83$.

See infra text accompanying notes $85-86$.

See infra text accompanying notes 87-91.

Wellerstein, supra note 6, at 109.

What's Culture Got to do With It?, supra note 30, at 1949.

See, e.g., O.M.T. Odujinrin, C.O. Akitoye \& M.A. Oyediran, A Study on Female Circumcision in Nigeria, 8 W. AFR. J. MED. 183, 187 (1989).

74 Harriet Lawrence, Excising a Harmful Tradition, GuARDIAN, June 11, 1992, at 9.

75 What's Culture Got to do With It?, supra note 30, at 1961.

76 Olayinka Koso-Thomas, The CirCuMCision OF WOMEN: A STRATEGy FOR ERADICATION 8-

78 Myers, supra note 5, at 584-85.

79 What's Culture Got to Do With It?, supra note 30, at 1951.
} 9 (1987).

77 Id. 
ran. $^{80}$ However, neither the Christian nor Islamic faiths require female genital mutilation. ${ }^{81}$ Combining both religious and societal notions, supporters argue that female genital mutilation is intended to prevent promiscuity and preserve chastity until marriage by removing an organ that supposedly causes women to become oversexed.

\section{Thwarting Promiscuity}

In addition to the religious arguments supporting chastity, advocates of female genital mutilation argue the prevention of promiscuity as a separate and distinct reason to maintain the practice. ${ }^{83}$ Supporters of the practice believe that the clitoris arouses women to make unruly sexual demands, which would perhaps drive a woman to seek extra-marital affairs to have such demands met. ${ }^{84}$ Thus, the removal of the clitoris is believed beneficial for women and for society. The main purpose for subjecting women to female genital mutilation is to control the woman's sexuality and reproductive functions. ${ }^{85}$

\section{Hygiene and Aesthetics}

Advocates of female genital mutilation also offer feminine hygiene and aesthetics as reasons for performing the practice. ${ }^{86}$ However, contrary to what supporters believe, mutilation does not make young girls and women cleaner. ${ }^{87}$ It actually leads to urine retention and the accumulation of menstrual blood in the vagina, which leads to discomfort, infection, and odors that are more unpleasant than those caused by normal hormonal secretions. $^{88}$ Moreover, female genital mutilation does not make the vulva aesthetically more attractive. ${ }^{89}$ The procedure causes post-operative scarring that results in a keloid stump and a long scar. ${ }^{90}$ Thus the procedure should not be performed as cosmetic surgery.

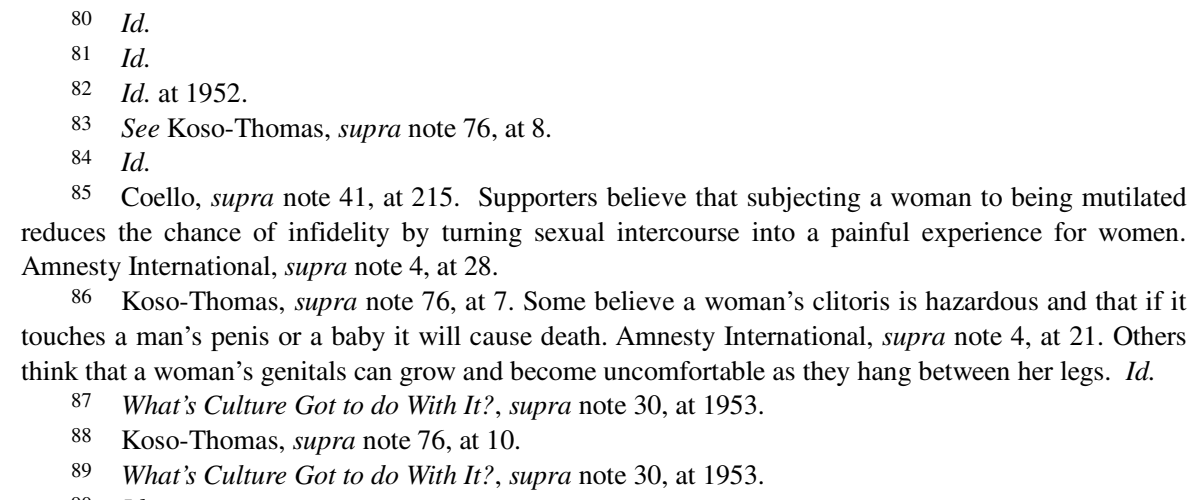

86 Koso-Thomas, supra note 76, at 7. Some believe a woman's clitoris is hazardous and that if it touches a man's penis or a baby it will cause death. Amnesty International, supra note 4 , at 21 . Others think that a woman's genitals can grow and become uncomfortable as they hang between her legs. Id.

87 What's Culture Got to do With It?, supra note 30, at 1953.

88 Koso-Thomas, supra note 76, at 10.

89 What's Culture Got to do With It?, supra note 30, at 1953.

$90 \quad I d$. 


\section{THE CRIMINALIZATION OF FEMALE GENITAL MUTILATION}

This Part analyzes the laws criminalizing female genital mutilation in the United States. Section A provides a history of female genital mutilation in the United States. ${ }^{91}$ Section B describes the Illegal Immigration Reform and Immigrant Responsibility Act of 1996. ${ }^{92}$ Section C discusses the only case up-to-date that has condemned the practice and the abrogation of the cultural defense. ${ }^{93}$ And, finally, section D analyzes Congress' power to ban female genital mutilation. ${ }^{94}$

\section{A. Female Genital Mutilation in the United States}

Female genital mutilation began in the United States in the early nineteenth century. ${ }^{95}$ After the Civil War, men and doctors developed an attitude of anxiety towards female emancipation and changing sex roles. ${ }^{96}$ During this time, American physicians believed that women were particularly susceptible to insanity because of their body's eccentric dominance over their mind. ${ }^{97}$ Thus, physicians theorized that sexual infidelity was a symptom of psychological disorders. ${ }^{98}$

Doctors began to treat psychological disorders through gynecological operations. 99 They thought that female genital mutilation would encourage women to stay in their traditional roles as dependent, submissive, and moral creatures. ${ }^{100}$ Eventually, physicians discarded the surgery as a cure for psychological disorders because, in most cases, the surgery failed its intended purpose. $^{101}$

American physicians no longer perform the procedure to treat psychological disorders; however, the attitudes and assumptions regarding gender roles that provided the original justification for these surgeries are still a part of our present culture. ${ }^{102}$ Therefore, with a history of tolerance for the practice of female genital mutilation in the United States and the knowledge that the practice continued to occur within our borders, it was imperative for the government to take action against the practice and prevent further

\footnotetext{
See infra text accompanying notes 96-105.

See infra text accompanying notes 106-21.

See infra text accompanying notes 122-60.

See infra text accompanying notes 161-279.

Barker-Benfield, supra note 8, at 285.

Id. at 280 .

$I d$. Doctor's believed that a woman's common sexuality drove her to madness. $I d$.

Id. at 283.

99 Id. at 284. Excision of the clitoris (clitoridectomy) and extirpation of the ovaries (female castration) were among the operations performed to cure mental defects. Id. at 280.

100 Id. at 287.

102 Isabelle R. Gunning, Arrogant Perception, World-Travelling and Multicultural Feminism: The Case of Female Genital Surgeries, 23 COLUM. HuM. RTS. L. REV. 189, 211 (1992).
}

101 Id. 
physical and emotional injury to young girls and women who have little or no say in the decision. Large numbers of immigrants from African countries reside in metropolitan areas such as New York City, Newark, Detroit, Atlanta, Washington, D.C., and Los Angeles. ${ }^{103}$ There have been reports of the ritual being performed in these areas. ${ }^{104}$ Thus, it is likely that many women have undergone or are at risk of being subjected to female genital mutilation.

\section{B. Illegal Immigration Reform and Immigrant Responsibility Act of 1996}

In September 1996, Congress passed the Illegal Immigration Reform and Immigrant Responsibility Act of 1996 (IIRAIRA), ${ }^{105}$ sponsored by Representative Patricia Schroeder and Senator Harry Reid, outlawing the ritual of female genital mutilation in the United States. ${ }^{106}$ The passage of the federal law was fostered by the enactment of several state laws banning the practice. $^{107}$ IIRAIRA recognizes several objectives, including requiring

103 Hughes, supra note 1, at 324.

104 Staff of Rep. Patricia Schroeder, 104Th CONG., 1St SESS., SuMmary OF Federal AND State Legislation on Female Genital Mutilation (1995) [hereinafter Summary of Federal and State Legislation].

105 The Federal Female Genital Mutilation Act, 18 U.S.C. § 116 (1996); Illegal Immigration Reform and Immigrant Responsibility Act of $1996 \S 645$ (1996).

106 The Act specifically provides:

(a) Except as provided in subsection (b), whoever knowingly circumcises, excises, or infibulates the whole or any part of the labia majora or labia minora or clitoris of another person who has not attained the age of 18 years shall be fined under this title or imprisoned not more than 5 years, or both.

(b) A surgical operation is not a violation of this section if the operation is-

(1) necessary to the health of the person on whom it is performed, and is performed by a person licensed in the place of its performance as a medical practitioner; or

(2) performed on a person in labor or who has just given birth and is performed for medical purposes connected with that labor or birth by a person licensed in the place it is performed as a medical practitioner, midwife, or person in training to become such a practitioner or midwife.

(c) In applying subsection (b)(1), no account shall be taken of the effect on the person on whom the operation is to be performed of any belief on the part of that person, or any other person, that the operation is required as a matter of custom or ritual.

Female Genital Mutilation Act $\S 116$.

107 Summary of Federal and State Legislation, supra note 104; Female Genital Mutilation Education and Outreach M.S.A. § 144.3872 (1994); Female Genital Mutilation 11 Del.C. § 780 (1996). States banning female genital mutilation include: California, Colorado, Delaware, Illinois, Maryland, Minnesota, North Dakota, Nevada, New York, Oregon, Rhode Island, Tennessee, Texas, and Wisconsin. CENTER for Reproductive LaW and Policy, Legislation on Female Circumcision Female Genital MUTILATION IN THE UNITED STATES, n.43, available at http://www.crlp.org/pub_art_fgmuslaws.html (last visited May 8, 2002) (cited in Christopher T. Paresi, Note, Symbolic Rites: Examining the Adequacy of Federal Legislation Addressing the Problem of Female Excision in the United States, 8 BUFF. Hum. RTs. L. Rev. 163, n.17 (2002)); Cal. Penal Code $§ 273.4$ (West 1996); Cal. Health \& SafeTy CODE $§ 124170$ (1996); Colo. Rev. Stat. § 18-6-401 (1999); Del. CodE ANN. tit. 11, § 780 (1996); Ill. Comp. Stat. Ann. § 5/12-34 (West 1997); Md. Code Ann. Health-Gen. I § 20(601) (1998); 
physicians to report incidents of female genital mutilation, banning the performance of the ritual by unlicensed medical practitioners, and guaranteeing that girls and women who have been subjected to the procedure will be free from discrimination by medical practitioners. ${ }^{108}$ In addition, IIRAIRA advocates for the development of educational programs for medical school students and calls for the creation and implementation of outreach activities that allow persons performing female genital mutilation and those trying to prevent female genital mutilation to collaborate to stop the practice.

The federal law defines female genital mutilation as a criminal act and provides that anyone who "knowingly circumcises, excises, or infibulates the whole or any part of the labia majora or labia minora or clitoris of another person who has not attained the age of 18 shall be fined . . . or imprisoned for not more than 5 years, or both."

IIRAIRA excuses practitioners who perform such medical procedures during specific circumstances from prosecution. ${ }^{111}$ It states that surgical procedures are not violative of the law when the operation is necessary to the woman's health and is performed by a licensed medical practitioner. ${ }^{112}$ It also allows practitioners to perform genital surgery on a woman in labor or who has just given birth for medical purposes in connection with that labor or birth. ${ }^{113}$ The person performing the procedure must be licensed to practice in the place in which it is being performed. ${ }^{114}$ Congress' primary intent was to eliminate the practice of performing female genital mutilation in people's houses without proper equipment and supervision. ${ }^{115}$

Besides providing penalties for disobeying the law, IIRAIRA contains an educational element. ${ }^{116}$ The Secretary of Health and Human Services is required to assemble data on the number of women living in the United States who have been subjected to female genital mutilation, including a compilation of the number of girls under the age of 18 who have been sub-

MinN. Stat. $\S \S 609.2245(1) \& 144.3872$ (West 1996); 2000 Mo. Legis. SERV. S.B. 602, $§ 568.065$ (Vernon's); N.D. Cent. Code § 12.1-36-01 (1995); Nev. Rev. Stat. ANN. § 200.5083 (1999); N.Y. PENAL LAW § 130.85 (Consol. 1997); Or. REv. STAT. § 163.207 (1999); R.I. GEN. LAWS § 11-5-2 (1996); TENN. CoDE ANN. § 39-13-110 (1996); and Wis. STAT. $\$ 146.35$ (West 1995). In addition, Louisiana and Hawaii legislatures have passed resolutions denouncing the practice. See H.C.R. 52, Reg. Sess. (La. 1996) (cited in Paresi, supra note 107, at n.163); see also H.C.R. 47, Twentieth Legislature (HI 2000).

108 Female Genital Mutilation Act $§ 116$; IIRAIRA $\S 645$; Sharif, supra note 5, at 418.

109 Information Regarding Female Genital Mutilation, 8 U.S.C. § 1374(a)(1) and (2) (1996); Illegal Immigration Reform and Immigrant Responsibility Act of $1996 \S 644(a)(1)$ and (2); Sharif, supra note 5 , at 418 .

110 Female Genital Mutilation Act § 116(a).

111 Id. $\S 116(\mathrm{~b})(1)$ and (2).

$112 I d . \S 116(\mathrm{~b})(1)$.

$113 I d . \S 116(\mathrm{~b})(2)$.

$114 I d . \S 116(\mathrm{~b})(2)$.

115 See id. $\$ 116$.

116 Information Regarding Female Genital Mutilation § 1374. 
jected to mutilation. ${ }^{117}$ The Secretary is also required to identify the individuals in the United States who practice female genital mutilation and create and implement outreach programs to educate them about the physical and psychological hazards associated with the practice. ${ }^{118}$ The Secretary's outreach activities must include association with representatives of ethnic groups that practice mutilation and representatives of organizations that have expertise in preventing it. ${ }^{119}$ Finally, the Secretary must develop recommendations for the education of medical school students about female genital mutilation and its medical complications. ${ }^{120}$

\section{Female Genital Mutilation in the Courtroom}

In 2003, the United States witnessed its first ever documented case of female genital mutilation with the arrest of Khalid Adem. ${ }^{121}$ Although the practice had been criminalized by federal statute since $1996,{ }^{122}$ there had not been any criminal indictments or prosecutions for female genital mutilation in the United States until Adem's arrest. ${ }^{123}$ Adem, a Georgia resident of Ethiopian decent, was charged with performing female genital mutilation on his two-year-old daughter. ${ }^{124}$ He had allegedly genitally mutilated his daughter in 2001, without his wife's knowledge or consent. ${ }^{125}$ Adem performed the practice in his home in Duluth with a pair of scissors. ${ }^{126} \mathrm{He}$ was found guilty on charges of cruelty to a child and aggravated battery. ${ }^{12}$

Adem was not convicted under the federal law banning female genital mutilation, but under a previously existing child battery law. ${ }^{128}$ He was sentenced to ten years in prison, followed by five years of probation. ${ }^{129}$ The current federal law criminalizing female genital mutilation provides a max-

117 Information Regarding Female Genital Mutilation $§ 1374$; IIRAIRA $\S 644$.

118 Information Regarding Female Genital Mutilation § 1374(a)(1); IIRAIRA § 644(a)(1).

119 Information Regarding Female Genital Mutilation $§ 1374(b)$; IIRAIRA $\S 644(b)$.

120 Information Regarding Female Genital Mutilation § 1374; IIRAIRA § 644.

121 State v. Adem, No. 04-B-01291-5 (Gwinnett County, Georgia, filed Feb. 27, 2004) (cited in Naomi Mendelsohn, Note, At the Crossroads: The Case For and Against a Cultural Defense to Female Genital Mutilation, 56 RUTGERs L. REV. 1011, 1011 (2004)).

122 Female Genital Mutilation Act, $\$ 116$.

123 State v. Adem, No. 04-B-01291-5 (cited in Naomi Mendelsohn, Note, At the Crossroads: The Case For and Against a Cultural Defense to Female Genital Mutilation, 56 RUTGERS L. REV. 1011, 1011 (2004)).

124 Lateef Mungin, Arrest Over Girl's Circumcision Could Signal Trend, ATL. J. CONST., Apr. 4, 2003, at C7.

125 Id.

126 Id.

127 Baron Bodissey, Khalid Adem Has Been Convicted, http://gatesofvienna.blogspot.com/2006/ 11/khalid-adem-has-been-convicted.html (last visited March 14, 2007).

128 Id.

129 Fausta's Blog, http://faustasblog.com/2006/11/female-genital-mutilation-and.html (last visited Jan. 15, 2008). 
imum prison sentence of five years for those prosecuted under the law. ${ }^{130}$ Perhaps the Georgia court wanted to send a strong message that the practice of female genital mutilation will not be tolerated, and therefore prosecuted Adem under child battery law to impose a greater sentence. ${ }^{131}$

\section{Abrogating the Cultural Defense: A Step in the Right Direction}

Supporters of female genital mutilation argue that since the practice is performed as an integral part of their culture, then the use of a cultural defense to mitigate criminal liability should be permitted. ${ }^{132}$ The current federal law states that "no account shall be taken of the effect on the person on whom the operation is to be performed of any belief on the part of that person, or any other person, that the operation is required as a matter of custom or ritual." ${ }^{, 133}$ Adem's case sends a strong message that anyone immigrating to the United States is subject to the rule of law. ${ }^{134}$ Their cultural practices are held to the same standards as the rest of the inhabitants of the United States. ${ }^{135}$

The cultural defense is used in situations in which an act of violence has been committed by an immigrant whose native land condones such an act. $^{136}$ It allows a defendant to mitigate criminal liability on the basis of the defendant's cultural belief that the act committed was reasonable due to the defendant's cultural values and traditions. ${ }^{137}$ It has most often been used in situations involving violent crimes against women and children. ${ }^{138}$

In People v. Wu, ${ }^{139}$ the California Court of Appeal held that the jury could take into consideration the defendant's cultural background when determining whether the defendant possessed the necessary mens rea to be found guilty of murdering her son. ${ }^{140}$ After discovering her husband's infidelity, $\mathrm{Wu}$ killed her son and then attempted to take her own life. ${ }^{141}$ The court determined that the defendant's behavior was a culturally-based reaction to protect her son and liberate herself of her husband's shameful beha-

130 Female Genital Mutilation Act § 116(a).

131 See Fausta, supra note 129.

132 Mendelsohn, supra note 121, at 1020.

133 Female Genital Mutilation Act, § 116(c).

134 Fausta, supra note 129.

135 Id.

136 Taryn F. Goldstein, Comment, Cultural Conflicts in Court: Should the American Criminal Justice System Formally Recognize, a "Cultural Defense"?, 99 DICK. L REV. 141, 143 (1994) (citing John C. Lyman, Cultural Defense: Viable Doctrine or Wishful Thinking?, 9 CRIM. JUST. J. 87 (1986)).

137 Julia P. Sams, The Availability of the Cultural Defense as an Excuse for Criminal Behavior, 16 GA. J. INT'L \& COMP. L. 335, 336 (1986).

138 Alice J. Gallin, The Cultural Defense: Undermining the Policies Against Domestic Violence, 35 B.C. L. REV. 723 (1994).

139 People v. Wu, 286 Cal. Rptr. 868 (Cal. Ct. App. 1991).

140 Id. at 887.

141 Id. at 885. 
vior. ${ }^{142}$ The court stated that in Asian culture a mother who commits suicide and therefore leaves her children alone is considered irresponsible. ${ }^{143}$ Therefore, the court held that it was necessary to take into account the defendant's cultural background to determine the existence of premeditation and whether malice aforethought and heat of passion existed.

Supporters of female genital mutilation argue that the practice must continue to preserve tradition. ${ }^{145}$ They specifically state that it is their right of cultural self-determination to continue with this tradition. ${ }^{146}$ Female genital mutilation is deeply rooted in many African and Islamic societies, and they argue that to eradicate the practice would impose outside values in their communities, which would interfere with their complex cultural system. ${ }^{147}$

However, a society maintains a cultural tradition when the original justifications for the tradition's existence validate its continuance today. ${ }^{148}$ "Conversely, those practices that have neither factual, historical validity nor contemporary legitimacy in terms of societal values, and that furthermore inflict harm and injury on their adherents, must be abandoned." societal beliefs do not support the continuation of female genital mutilation as a societal tradition, religious requirement, control of female sexuality, or aesthetics. ${ }^{150}$ These arguments fail to endorse the continued existence of a practice that is so harmful. ${ }^{151}$ Immigrant communities in the United States should not have the right to continue with a tradition, simply for the sake of tradition, that causes so much physical, emotional, and sometimes even fatal harm to women and young girls. ${ }^{152}$ An immigrant has the duty to understand and abide by the laws in the United States. ${ }^{153}$

The law has to be respected by any person being on national soil. Foreigner customs must submit to the law. If not, we would be committing an unacceptable discrimination based on the girls' origin. It

142 Id. at 887.

143 Id. at 885.

144 Id. at 887.

145 Alison T. Slack, Female Circumcision: A Critical Appraisal, 10 HuM. RTS. Q. 437, 462 (1988).

146 Id.

147 Id. at 463.

148 What's Culture Got to do With It?, supra note 30, at 1960.

149 Id.

$150 I d$. at 1960.

151 Id. at 1960.

152 Hughes, supra note 2, at 355. "Imposing certain values on people living in this country is our prerogative. There are a number of practices that immigrants are required to leave at home when they move here. Polygamy and slavery are two very obvious examples." Patricia Schroeder, Female Genital Mutilation - A Form of Child Abuse, 331 New Eng. J. MED. 739, 739 (1994).

153 Goldstein, supra note 136, at 158. 
would mean that, though we find the idea of cutting a white girl's clitoris scandalous we accept it being done to an African girl. ${ }^{154}$

Recognition of a cultural defense has a negative effect on the victims of violent acts, such as female genital mutilation, and those committing such acts. ${ }^{155}$ This means that young girls and women can be subjected to this unhygienic and painful practice by their families in order to comply with personal ideas of purity and chastisement. The recognition of a cultural defense would mean that the United States consents to the violence being committed against women around the world. If a cultural defense can exculpate practitioners then women and young girls are not being protected. "Judicial acceptance of a cultural defense would be disastrous for immigrant women in the United States . ..."156 The United States has never recognized ignorance of the law as a defense to criminal prosecution. ${ }^{157}$

Allowing such a defense would run opposite of our criminal justice objectives, which are general and specific deterrence. ${ }^{158}$ The women would not be protected from violence, and the young girls would not be protected from abuse. ${ }^{159}$ Hence, although the cultural defense is permitted in other criminal cases, the legislature's decision to abrogate the defense in female genital mutilation cases is appropriate and a step in the right direction.

\section{Congress' Power to Outlaw Female Genital Mutilation}

This section analyzes the constitutionality of the law prohibiting female genital mutilation. Section 1 analyzes the law under the Commerce Clause. $^{160}$ Section 2 provides an analysis of the law under the First Amendment. ${ }^{161}$ Finally, section 3 discusses the constitutional right to selfdetermination and personal autonomy. ${ }^{162}$

\section{The Commerce Clause Analysis}

If challenged, Section 645 of IIRAIRA would be found constitutional under the Commerce Clause. ${ }^{163}$ Absent uniform legislation prohibiting fe-

154 Coello, supra note 41, at 213 (citing E-mail interview with Linda Weil-Curiel, Sept. 9, 1998).

155 Gallin, supra note 138, at 735-37.

156 Goldstein, supra note 136, at 163.

157 Julia P. Sams, The Availability of the Cultural Defense as an Excuse for Criminal Behavior, 16 GA. J. INT’L \& COMP. L. 335, 337 (1986).

158 Id.

159 Goldstein, supra note 136, at 163.

160 See infra text accompanying notes 166-182.

161 See infra text accompanying notes 183-229.

162 See infra text accompanying notes 230-81.

163 U.S. CONST. art. I, § 8. The Commerce Clause states that "Congress shall have Power [t]o ... regulate Commerce . . among the several States ...." Id. Courts will uphold commerce-based laws if there is any rational basis upon which Congress could find some relation between its regulation and interstate commerce. Hodel v. Virginia Surface Mining \& Recl. Ass'n, 452 U.S. 264, 276, 283 (1981). 
male genital mutilation, families can travel from state-to-state to acquire the operation in those states that allow female genital mutilation and from doctors who perform the procedure. ${ }^{164}$ The federal law banning female genital mutilation deters such families from moving in interstate commerce to obtain the surgery. Congress is authorized to make such laws that are "necessary and proper for carrying into execution" any of the enumerated powers. ${ }^{165}$ As interpreted in the landmark case McCulloch v. Maryland, ${ }^{166}$ the Necessary and Proper Clause gives Congress the power to use the means calculated to produce an end; such means may be "convenient, useful or essential" in achieving a desired end that is defined in an enumerated power. $^{167}$

The Constitution specifically grants Congress the power to regulate interstate commerce. ${ }^{168}$ Congress has broad discretion in passing laws to control interstate commerce. ${ }^{169}$ The Supreme Court set out four theories under which a commerce-based regulation can be based. ${ }^{170}$ First, Congress has the power to regulate purely intrastate activity, as long as, the regulation of such activity has a "close and substantial relation" to interstate commerce. ${ }^{171}$ Second, Congress has the power to regulate intrastate activity if the cumulative effect of such activity interferes with interstate commerce. ${ }^{172}$ Third, Congress "may choose the means reasonably adapted to the attainment of the permitted end, even though they involve control of intrastate activities." ${ }^{\prime 17}$ Congress' power was extended to include intrastate activities which have an effect on interstate commerce or the exercise of congressional power over interstate commerce, making the regulation of the intrastate activities a suitable means to accomplishing a lawful end. ${ }^{174}$

Finally, Congress has the power, via the Commerce Clause, to bar the transportation of women in interstate commerce for immoral purposes, specifically prostitution. ${ }^{175}$ The Supreme Court defined commerce among the states as "intercourse and traffic between their citizens, and include[s] the

164 Hughes, supra note 1, at 337.

165 U.S. CONST. art. I, $\S 8$.

16617 U.S. 316 (1819).

167 Id. at 413 .

168 U.S. CONST. art. I, $\S 8$.

169 Hughes, supra note 1, at 338.

170 NLRB v. Jones \& Laughlin Steel Corp., 301 U.S. 1, 37 (1937); Wickard v. Filburn, 317 U.S. 111, 127-28 (1942); United States v. Darby, 312 U.S. 100, 121 (1941); Hoke v. United States, 227 U.S. 308, 320 (1913).

171 NLRB, 301 U.S. at 37.

172 Wickard, 317 U.S. at 127-28.

173 Darby, 312 U.S. at 121.

174 Id. at 118.

175 Hoke, 227 U.S. at 320. 
transportation of persons and property . . . [;] a person may move or be moved in interstate commerce."

Female genital mutilation is mostly a purely intrastate activity that occurs within the state's borders. However, if the various states have the option to enact or not enact laws regulating female genital mutilation, families who desire the operation will likely travel between states to procure the procedure. Differing intrastate practices of female genital mutilation would have a "close and substantial relation" to interstate commerce and calls for national regulation according to the $N L R B$ test.

Second, to permit various individual doctors to decide if they will perform female genital mutilation will likely result in transporting women by roadways, railway, or airways to obtain the operation. Allowing state legislatures or individual physicians to make the decision to either allow or prohibit female genital mutilation would also induce the movement of these women and young girls in interstate commerce.

Third, Congress has the power to regulate the intrastate practice of female genital mutilation because frequent traveling, due to difficulties that occur after surgery and the movement of families between states, will have an obvious effect on interstate commerce. ${ }^{178}$ Finally, the movement of persons between the states is considered commerce. Thus, under the definition set forth in Hoke, the transportation of women and young girls between the states to obtain the surgery is interstate commerce. ${ }^{179}$ Thus, the federal law banning female genital mutilation is constitutional because it falls within Congress' power to regulate interstate commerce, and it also helps establish uniformity among the states when dealing with this particular subject.

\section{The First Amendment Analysis}

The First Amendment to the Constitution of the United States contains two clauses aimed to protect religious freedom. First, it provides that "Congress shall make no law respecting an establishment of religion."180 Second, it forbids any law from "prohibiting the free exercise thereof . . . ." These two clauses have been held to demand that "government neither engage in nor compel religious practices, that it effect no favoritism among sects or between religion and nonreligion and that it work deterrence of no religious belief." 182 Both clauses apply to the states via the Fourteenth

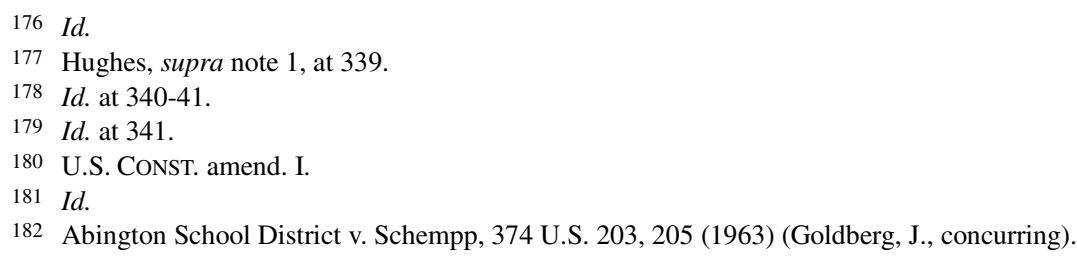


Amendment. ${ }^{183}$ In applying these two clauses, the Court looks at the legitimacy of a belief and the religiousness of a belief in determining whether to prohibit federal regulation under the Free Exercise Clause. ${ }^{184}$ A particular religious belief must also be essential to the individual's religion to be excused from federal and state regulation. ${ }^{185}$

Female genital mutilation is not a scripturally mandated ritual. ${ }^{186} \mathrm{Nei}-$ ther Christianity ${ }^{187}$ nor Islam require that it be performed. ${ }^{188}$ Therefore, it is more appropriately characterized as a cultural tradition that is not protected from government regulation by the First Amendment. ${ }^{189}$ Alternatively, even if female genital mutilation were considered a religious belief, it would pass a strict scrutiny analysis because the government has a compelling interest in protecting young girls and women from the serious physical and emotional implications associated with female genital mutilation. ${ }^{190}$

a) The Establishment Clause. The Supreme Court established that governmental action violates the Establishment Clause when it fails to satisfy a three-pronged test. ${ }^{191}$ An action must meet each of the following conditions: "(1) it must have a secular legislative purpose; (2) its primary effect must neither advance nor inhibit religion; and, (3) it must not foster an excessive government entanglement with religion." 192 Under this analysis, the criminalization of female genital mutilation does not violate the Establishment Clause.

First, the criminalization of female genital mutilation advances a secular purpose, the prevention of child abuse. ${ }^{193}$ Second, the primary effect of criminalizing female genital mutilation would neither advance nor inhibit religion because all religions would be equally free to exist and worship, regardless of whether female genital mutilation is practiced or not. ${ }^{194}$ Third, the criminalization of female genital mutilation would not foster an excessive government entanglement with religion. The government would play

183 Everson v. Board of Education, 330 U.S. 1 (1947).

184 Hughes, supra note 1, at 345.

185 Thomas v. Review Bd. Ind. Empl. Sec. Div., 450 U.S. 707 (1981) (challenging a state's denial of unemployment benefits to a Jehovah's Witness who resigned from his job because of his religious beliefs, even though evidence suggested that there were other Jehovah's Witnesses who were able to work this same job).

186 Hughes, supra note 1, at 342; What's Culture Got to do With It?, supra note 30, at 1952.

187 However, some tribes, such as those in Kenya, which have converted to Christianity, believe that young girls will be condemned to hell if they do not submit to the practice. Hughes, supra note 1, at 342 .

$188 I d$. at 342. Many Muslims incorrectly believe that the Koran requires women to undergo female genital mutilation. $I d$. at 343 .

189 Id.

$190 I d$. at 342.

191 Lemon v. Kurtzman, 403 U.S. 602 (1971).

192 Id. at 612-13.

193 Larson, supra note 9, at 251.

194 Id. 
no part in religious matters, other than making sure that women and young girls, for health reasons, are not subjected to female genital mutilation.

Criminalizing female genital mutilation does not violate the Establishment Clause because the government would neither be forcing nor coercing individuals to acknowledge a belief in a certain religion, nor would the government be punishing individuals for practicing a specific religion. ${ }^{196}$ The criminalization of female genital mutilation would only affect one small aspect of the religion, which is not crucial to religious worship. ${ }^{197}$ Therefore, the criminalization of female genital mutilation does not violate the Establishment Clause.

b) The Free Exercise Clause. There is no clear test for determining when a violation of the Free Exercise Clause has occurred; however, the Supreme Court has recognized that freedom of religion may be reduced in the interest of society. ${ }^{198}$ In Church of Lukumi Bablu Aye, Inc. v. Hialeah, ${ }^{199}$ the Court stated that when the government's purpose is to negatively affect a specific type of conduct merely because such conduct is dictated by a particular religion, the government action will not be upheld. ${ }^{200}$ The Court has held that this kind of government action must be neutral and of general applicability. $^{201}$

The IIRAIRA is a neutral law of general applicability. The governmental purpose in banning female genital mutilation is not to negatively impact the Islamic religion, but to forbid a practice in the interest of the health and welfare of women and young girls. In addition, female genital mutilation is also considered a criminal act of child abuse. ${ }^{202}$ Cultures that practice female genital mutilation would be equally affected regardless of whether they perform the practice as a tradition or a religious belief. ${ }^{203}$ Hence, the criminalization of female genital mutilation passes strict scrutiny under the standards set forth in Church of Lukumi Bablu Aye.

Nevertheless, most cases involving the Free Exercise Clause do not involve an unlawful purpose to limit a certain religion. Generally, religious freedom cases involve governmental action that has the accidental result of burdening religiously-motivated conduct. ${ }^{204}$ In Reynolds $v$. United States, ${ }^{205}$

$195 I d$.

196 Id.

197 Id.

198 Reynolds v. United States, 98 U.S. 145 (1878).

199508 U.S. 520 (1993).

200 Church of Lukumi Bablu Aye, 508 U.S. at 523 (holding that a city ordinance dealing with the ritual slaughter of animals (1) was not neutral; (2) were not of general applicability; and (3) the government interest advanced by the ordinances did not justify the targeting of religious activity).

201 Id. at 523.

202 Larson, supra note 9, at 252.

203 Id.

204 Id. 
the Supreme Court held that although the state could not restrict religious beliefs, it could restrict religious practices that are harmful to society. ${ }^{206}$ The government has often used this distinction between religious beliefs and the resulting religious practice to regulate activities that the government believes are harmful to the participants or the public. ${ }^{207}$ The Supreme Court held that a general state law that is designed to advance legitimate secular goals is valid despite an indirect encumbrance on religious practices. ${ }^{208}$

In Sherbert v. Verner, ${ }^{209}$ the Supreme Court narrowed this holding by implementing the "compelling state interest" test, which provides that even laws that only have an indirect effect on religious freedom must meet the requirements. ${ }^{210}$ According to the Sherbert standard, "[o]nly the gravest abuses, endangering paramount interests, give occasion for permissible limitation [of religious freedom]." ${ }^{211}$ However, the Court also stated that "certain overt acts prompted by religious beliefs or principle, . . . 'even when the action is in accord with one's religious convictions, ... [are] not totally free from legislative restrictions." " 212 The health and safety of young girls and women is a compelling state interest that justifies government interference in religious practices to protect the general welfare of its people. Preventing the unwanted genital mutilation of female children is a "grave abuse endangering paramount interests." ${ }^{113}$ Therefore, restricting religious freedom by prohibiting the practice of female genital mutilation complies with the standard set forth in Sherbert.

Criminal prohibition on certain types of behavior that is not intended to burden religious beliefs, but incidentally does so, has been held to be valid. $^{214}$ In Employment Division, Department of Human Resources of Oregon v. Smith, ${ }^{215}$ the Supreme Court upheld Oregon's refusal to exempt a Native American from a criminal law prohibiting the use of peyote, even though peyote is a central part of their religious practices. ${ }^{216}$ The Court reasoned that it was not obligated to weigh the state's interest in the prohi-

\footnotetext{
205 Reynolds v. United States, 98 U.S. 145 (1878) (holding that the Mormon practice of bigamy could be criminally prosecuted).

206 See generally id.

207 William E. Brigman, Circumcision as Child Abuse: the Legal and Constitutional Issues, 23 J. FAM. L. 337, 352 (1984).

208 See also id. at 346.

209 Sherbert v. Verner, 374 U.S. 398 (1963) (holding that the state could not deny unemployment benefits to an individual who was fired as a result of her failure to work on Saturdays due to her religious beliefs).

$210 \mathrm{Id}$. at 406.

211 Id.

212 Id. at 403 (quoting Braunfield v. Brown, 366 U.S. 599, 603 (1961)).

213 Larson, supra note 9, at 252.

214 See Employment Div., Dep't of Human Res. of Or. v. Smith, 494 U.S. 872 (1990).

215 Id.

$216 I d$.
} 
bition against the burden on religious beliefs, ${ }^{217}$ because the prohibition was enforceable so long as the ban on peyote was generally applicable and not motivated by a governmental interest in affecting a specific religion. ${ }^{218}$ An individual cannot be exempt from abiding by the law, as long as the law is not specifically directed against a religious practice and is constitutional as it is applied to those who engage in the prohibited act for nonreligious reasons.

Employment Division implies that a criminal prohibition that is generally applicable may be enforced even against those upon whom it causes an extreme religious burden, as long as the government's intention is not to cause such burden. ${ }^{220}$ Hence, the criminalization of female genital mutilation would pass strict scrutiny under Employment Division. However, prohibiting female genital mutilation would not have the effect of causing an extreme burden on religious beliefs. The proscription against female genital mutilation is generally applicable. Female genital mutilation is a criminal offense, regardless of whether it is practiced for religious or cultural reasons. Furthermore, the banning of female genital mutilation is not based on a desire to influence the Islamic religion, but instead to protect the health, safety, and welfare of young girls and women. Criminalizing female genital mutilation would not destroy the Islamic religion. ${ }^{221}$ Those who remain true to the faith are still free to worship where, when, and how they please.

Female genital mutilation is not mentioned in the Quran, the sacred bible of the Islamic religion. ${ }^{222}$ Accordingly, many Muslim women claim that it is not required by Islam. ${ }^{223}$ Some Islamic countries, for example, Saudi Arabia, do not even practice female genital mutilation. ${ }^{224}$ Therefore, the criminalization of female genital mutilation without religious exceptions does not destroy a ritual that is critical to the religion itself, nor does the state interfere with religious worship. Moreover, banning female genital mutilation does not violate the Free Exercise Clause, under the standard set forth in Employment Division.

Courts have allowed the government to carry out its actions concerning religion even when the government action has had the effect of making it more difficult for an individual to practice her religion; and the govern-

217 Id.

218 Id.

219 Id.

220 Larson, supra note 9, at 252.

221 Wisconsin v. Yoder, 406 U.S. 205 (1972) (holding that to prevent Amish parents from withdrawing their children from public schools would destroy the religion itself).

222 What's Culture Got to do With It?, supra note 30, at 1947.

223 Smith, supra note 39, at 2472.

224 See Smith, supra note 39, at 2471. 
ment's interest is weak, while the individual's interest is great. ${ }^{225}$ The government's interest in protecting the physical and psychological health, safety, and welfare of women and young girls is definitely a compelling interest. In the past, the Supreme Court has continuously upheld governmental actions that are much more burdensome on religious conduct. ${ }^{226}$ Therefore, the ban on female genital mutilation passes the strict scrutiny test that is applied to actions that incidentally burden religious freedom.

\section{The Right to Self-Determination}

Courts have upheld the constitutional protection regarding the fundamental right of self-determination and have recognized a private realm of family life that is outside of the state's control. ${ }^{227}$ The honor of the family has been protected under the Equal Protection Clause of the Fourteenth Amendment, ${ }^{228}$ and the Nineteenth Amendment. ${ }^{229}$ "A person's 'own good, either physical or moral, is not a sufficient warrant' for society to exercise power over that person. ${ }^{230}$ With regard to conduct 'which merely concerns [her] self, [her] independence is, of right, absolute.",231

However, if the right to self-determination were absolute, there would be no seatbelt and helmet laws, ${ }^{232}$ no laws restricting voluntary sexual activities between adults, ${ }^{233}$ and no legal restraints on suicide. ${ }^{234}$ Protecting others from harm is a suitable task for legal rules. ${ }^{235}$ The protection these rules should provide is a matter of cautious judgment or a balancing of morally relevant factors. $^{236}$ The prevention of harm to others is focused on the prevention of harm that is most directly imposed on people collectively. ${ }^{237}$

225 See Lying v. Nw. Indian Cemetery Protective Assoc., 485 U.S. 439 (1988) (holding that the federal government could build a road through federal land, even though it would destroy certain Native American traditional rites, with only a small benefit to federal interest).

226 Larson, supra note 9, at 254.

227 Id. at 248 (citing William E. Brigman, Circumcision as Child Abuse: the Legal and Constitutional Issues, 23 J. FAM. L. 337, 343 (1984)).

228 Skinner v. Oklahoma, 316 U.S. 535 (1941) (holding an Oklahoma statute that provided for sterilization of persons convicted three times of felonies showing "moral turpitude" to be unconstitutional under the Equal Protection Clause because the statute did not apply to white-collar crimes, such as embezzlement). The Court based its decision on the principle that "marriage and procreation are fundamental to the very existence and survival of the race." Id. at 541.

229 Griswold v. Connecticut, 381 U.S. 479 (1965) (Goldberg, J., concurring) (holding that the state could not prohibit married couples from using contraceptives).

230 Kent Greenawalt, Comment, Legal Enforcement of Morality, 85 J. CRIM. L. \& CRIMINOLOGY 710, 717 (1995) (citing JOHN STUART MiLl, ON LiBERTY 15 (Oxford University Press ed. 1975)).
231 Id.
232 Id.
233 Id.
234 Id.
235 Id. at 711.
236 Id.
237 Id. at 712. 
When considering the defensibility against legal "paternalism" that protects people from themselves, one must consider: "voluntary choice, paternalism that serves the reflective values of the actor, and paternalism that imposes values that the actor rejects." ${ }^{238}$ If there is voluntary choice, then restrictions on values that the actor accepts are less severe restrictions on autonomy than restrictions on values that the actor rejects. ${ }^{239}$

Banning the practice of female genital mutilation does not violate a woman's right to self-determination and personal autonomy. ${ }^{240}$ Women in cultures that practice female genital mutilation are very affected by their belief that their worth is tied to their sexuality. ${ }^{241}$ Hence, they "voluntarily" undergo the procedure. ${ }^{242}$ Some women are so affected by this belief that they undergo periodic re-mutilation after marriage to satisfy their husbands. ${ }^{243}$

Also, performing this significant cultural rite gives these women a feeling of power and importance which they are reluctant to give up. ${ }^{244}$ Their "voluntariness" to undergo this procedure is fueled by psychological beliefs that have been engraved into their minds throughout their lives. ${ }^{245}$ Therefore, these women do not act out of their right to self-determination and personal autonomy to do as they please with their bodies. Instead, they act out of psychological ideals of social inequality that are engraved in their minds since the day they are born. ${ }^{246}$ Hence, "self-determination" does not really factor into the decision of women from these societies to undergo this painful and unnecessary procedure.

Once these women realize that these "ideals" are not necessary to achieve womanhood, they reject the practice. This idea is reinforced by asylum cases involving women who face female genital mutilation. ${ }^{247}$ These women realize the unnecessary risk and dangers associated with the

238 Id. at 718.

239 Id.

240 Wellerstein, supra note 6, at 111.

241 Id. (citing Fran P. Hosken, The Hosken Report: Genital and Sexual Mutilation of Females 33 (4th rev. ed. 1994)); Fran P. Hosken, Female Genital Mutilation: Strategies for Eradication, First International Symposium on SEXual Mutilations, Mar. 1-3, 1989, http://www.nocirc.org/symposia/first/hosken.html.

242 Wellerstein, supra note 6, at 111.

243 Id. (citing Fran P. Hosken, The Hosken Report: Genital and Sexual Mutilation of FEMALES 33 (4th rev. ed. 1994)); Fran P. Hosken, Female Genital Mutilation: Strategies for Eradication, First International Symposium ON SEXUAL Mutilations, Mar. 1-3, 1989 http://www.nocirc.org/symposia/first/hosken.html.

244 Liu, supra note 52, at 84 . In Kenya, female genital mutilation is the only ritual for which women have full responsibility; therefore, giving it up would result in women losing an important role in the community. Layli Miller Bashir, Female Genital Mutilation in the United States: An Examination of Criminal and Asylum Law, 4 AM. U.J. GENDER \& L. 415, 426 n.75 (1996).

245 See Wellerstein, supra note 6, at 111.

246 See id.

247 Steele, supra note 2, at 108. 
practice and recognize that they are not inferior to males. ${ }^{248}$ Many women fight to protect their daughters from the unnecessary pain and trauma caused by the practice. ${ }^{249}$ There have been numerous cases of women seeking asylum in the United States to avoid female genital mutilation. ${ }^{250}$

Lydia Oluloro, a Nigerian woman who asked to stay in the United States to prevent her two daughters from being genitally mutilated, was the first undocumented immigrant to be granted asylum in the United States to protect her daughters from the practice. ${ }^{251}$ According to Oluloro, all of the women in her family had been genitally mutilated, and her family had assured her that if she returned to her country her daughters would be genitally mutilated as well. ${ }^{252}$ Oluloro recognized that "[her] blood was shed for no reason. "253 Judge Kendall Warren, who decided Oluloro's case said: "This court attempts to respect traditional cultures . . . But this FGM is cruel and serves no medical purpose. It's obviously a deeply ingrained cultural tradition going back 1,000 years at least."

Fauziya Kasinga, a seventeen-year-old girl from Togo who was a member of the Tchamba-Kunsuntu Tribe, was also granted asylum in the United States for fear of being subjected to female genital mutilation in her country. ${ }^{255}$ The INS Court recognized female genital mutilation as a form of persecution. "Persecution can consist of the infliction of harm or suffering by a government, or persons a government is unwilling or unable to control, to overcome a characteristic of the victim." 257 The Court found that the persecution was related to a "particular social group.",258 Therefore, because Kasinga had a well-founded fear of persecution and because she belonged to a "particular social group" the INS Court granted her request for asylum. ${ }^{259}$

248 See id.

249 Id.

250 Id. at 109. In 1993, Canada was the first country to grant asylum based on a fear of being subjected to female genital mutilation. See Clyde H. Farnsworth, Canada Gives Somali Mother Refugee Status, N.Y. TimES, July 21, 1994, at A1; Abankwah v. INS, 185 F.3d 18 (2d Cir. 1999); Bah v. Gonzales, 462 F.3d 637 (6th Cir. 2006); Abay v. Ashcroft, 368 F.3d 634 (6th Cir. 2004); Olowo v. Ashcroft, 368 F.3d 692 (7th Cir. 2004).

251 Steele, supra note 2, at 108 (citing Female Circumcision Issue in Deportation Case, WASH. Post, Feb. 8, 1994, at C2).

252 Id. (citing Female Circumcision Issue in Deportation Case, WASH. Post, Feb. 8, 1994, at C2).

253 Id. (citing Nigerians Spared Deportation, N.Y. TIMES, Mar. 24, 1994, at A19).

254 Id. (citing Court Alllows Nigerian Family To Stay in U.S., St. Petersburg Times, Mar. 24, 1994, at 1A).

255 In re Fauziya Kasinga, 21 I. \& N. Dec. 357, 368 (1996).

$256 I d$. at 365.

257 Id. (citing In re Acosta, 19 I \& N Dec. 211, 222-23 (1985)).

258 Id.

259 Id. at 368. 
Furthermore, state governments have banned several other practices without regard to self-determination and personal autonomy. ${ }^{260}$ These practices include polygamy ${ }^{261}$ and assisted suicide. ${ }^{262}$

a) Polygamy. Polygamy is part of a religious doctrine. ${ }^{263}$ Unlike female genital mutilation, polygamy is a practice that has no physical implications associated with it. ${ }^{264}$ However, it promotes social inequality. ${ }^{265}$ The practice of polygamy serves to promote the superiority of men over women. $^{266}$ Hence, most state governments have enacted legislation banning the practice. $^{267}$

It should be an individual's personal prerogative to determine whether they choose to marry multiple spouses. Polygamy practicing communities do not physically harm anyone with their practice. ${ }^{268}$ They do not inflict any type of pain or cause death. ${ }^{269}$ However, the social implications that polygamy advances have been sufficient to create a compelling state interest in upholding and enforcing its prohibition to protect the monogamous marriage relationship. ${ }^{270}$

b) Suicide. The state has an underlying interest in preventing suicide. $^{271}$ This interest is the prevention of irrational self-destruction. ${ }^{272}$ The right to die is a choice of self-determination and personal autonomy. ${ }^{273}$ However, the state has found a sufficiently compelling state interest that allows it to regulate a person's personal decision regarding her right to die. ${ }^{274}$ Similar to female genital mutilation, the right to commit suicide in-

260 See infra notes 263-264 and accompanying text.

261 The Utah code prohibits polygamy in Utah by outlawing bigamy. UTAH CODE ANN. § 76-7-101 (1973). The code specifically provides: "A person is guilty of bigamy when, knowing he has a husband or wife or knowing the other person has a husband or wife, the person purports to marry another person or cohabits with another person." Id. Polygamy is also prohibited by the Utah Constitution, specifically stating: "Perfect toleration of religious sentiment is guaranteed. No inhabitant of the State shall ever be molested in person or property on account of his or her mode of religious worship; but polygamous or plural marriages are forever prohibited." UTAH CONST. art. III $§ 1$.

262 The right of an individual to refuse medical treatment is subject to being overridden by state interests in certain circumstances. In re Fox, 423 N.Y.S.2d 580, 593 (1979). These state interests include the preservation of life, the protection of the interests of innocent third persons, the prevention of suicide, and maintenance of the ethical integrity of the medical profession. Leach v. Akron Medical Center, 68 Ohio Misc. 1 (1980).

263 Bronson v. Swensen, 394 F.Supp.2d 1329, 1330 (2005).

264 See id. at 1332.

265 See Reynolds, 98 U.S. at 150.

266 See id.

267 UTAH CODE ANN. § 76-7-101 (1973).

268 See generally Bronson, 394 F.Supp.2d at 1329.

269 See generally id.

270 Id. at 1332.

271 Foody v. Manchester Mem'1 Hosp., 40 Conn. Supp. 127, 133 (1984); 22A Am. Jur. 2d Death § 454.

272 Death, 22A Am. Jur. 2d Death $§ 454$

273 Foody, 40 Conn.Supp. at 132; In re Fox, 423 N.Y.S.2d at 593.

274 Foody, 40 Conn.Supp. at 133. 
volves grave physical implications. The government can regulate the personal interests of an individual when it involves that individual's decision of whether to end his/her life. ${ }^{275}$

As with these two practices, the government should be able to regulate an adult woman's right to self-determination and personal autonomy when it comes to undergoing female genital mutilation. The government has a sufficient state interest in preserving female integrity. ${ }^{276}$ Moreover, like polygamy, female genital mutilation promotes social inequality. ${ }^{277}$ The practice is designed to make women feel inferior to men. ${ }^{278}$ Therefore, female genital mutilation should be banned for women in addition to young girls.

\section{STRENGTHENING THE U.S. VoICE AGAINST FEMALE GENITAL MUTILATION}

The international community has taken a strong stance against female genital mutilation. ${ }^{279}$ This Part discusses the international resolutions to female genital mutilation. Section A discusses the two international theories on how to deal with cultural norms. ${ }^{280}$ Section $\mathrm{B}$ examines the laws banning female genital mutilation in various countries. ${ }^{281}$ Finally, section $\mathrm{C}$ proposes that the United States expand the current law banning female genital mutilation and follow in the international footsteps. ${ }^{282}$

\section{A. Differing International Theories: Which Should Apply?}

Legislators and legal scholars debate over how to reconcile societal differences with the concept of a greater international community. ${ }^{283}$ There are two theories that address the issue of female genital mutilation. ${ }^{284} \mathrm{Sec}-$ tion One will discuss the theory of cultural relativism, ${ }^{285}$ and section Two will discuss the theory of universalism. ${ }^{286}$

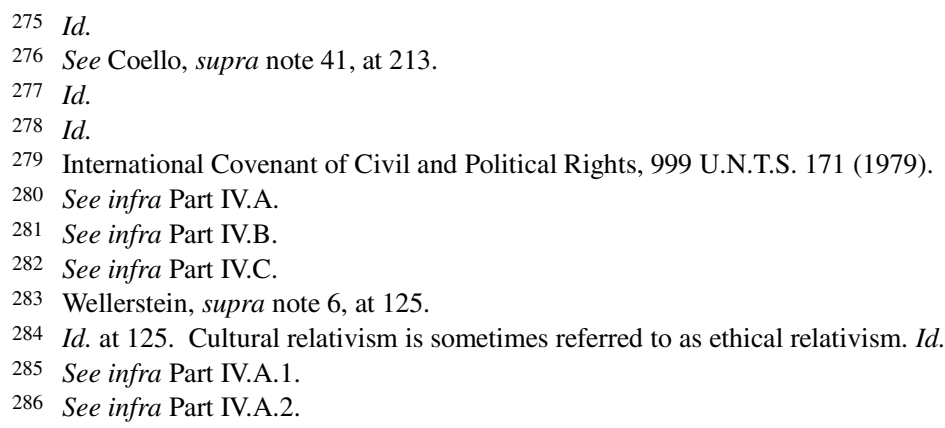




\section{Cultural Relativism}

The theory of cultural relativism is based on the fact that every culture has the right to set forth its own rules and customs and no one outside that community has the right to interfere. ${ }^{287}$ "Ethical relativism is viewed as an attitude of tolerance and as an antidote to the efforts of cultures who try their best to impose their set of moral rules on other cultures." ${ }^{288}$ Unequivocal tolerance to cultural norms may sound like an appealing notion; however, it can be very dangerous when carried out to its logical end. ${ }^{289}$ For example, few would contend that the world nations overstepped their boundaries when they obstructed the Nazi plan to eliminate Jews. ${ }^{290}$ True cultural relativists would argue that the world nations had no right to interfere and end the death camp. ${ }^{291}$ Instead, they should have allowed the genocide to continue. ${ }^{292}$

Genocide attempts are considered good reasons for justified intervention by the rest of the world. ${ }^{293}$ However, in the eyes of a cultural relativist, we are only against genocide because it is contrary to the norms of our own culture; for other cultures, genocide may be right. ${ }^{294}$ Fortunately, international law emphasizes that absolute tolerance is not enough and that there are certain standard universal human rights that must be followed. ${ }^{295}$ Since the catastrophic violence of World War II, international law has maintained a strong stance against human rights violations. ${ }^{296}$ "For all its positive elements, ethical relativism has a problem with allowing for a tolerance that objects to nothing, not even crimes against humanity . . ..,297

\section{Universalism}

The universalist believes that, regardless of any "physical separation, all people share a basic moral code." ${ }^{, 298}$ Although there are different degrees of universalism, "the underlying belief is the same."299 "The "soft univer-

287 See Nina Rosenstand, The Moral of THE Story: An InTRODUCTION TO Questions of ETHICS AND HUMAN NATURE 64, 65 (1994) (explaining the four approaches to the "phenomenon of moral differences": moral nihilism, ethical relativism, soft universalism, and hard universalism).

288 Id. at 65

289 Wellerstein, supra note 6, at 125.

290 Id.

291 Id.

292 Id.

293 Id. at 126.

294 Rosenstand, supra note 287, at 71-72.

295 See Universal Declaration of Human Rights, G.A. Res. 217A (III), art. 25, U.N. GAOR, 3d Sess., 1st plen. mtg., U.N. Doc. A/810 (Dec. 12, 1948).

296 Wellerstein, supra note 6, at 126.

297 Rosenstand, supra note 287, at 65.

298 Id.

299 Wellerstein, supra note 6, at 126. 
salist ${ }^{300}$ believes that all people share some common morals", ${ }^{301}$ while the "hard universalist" "302 believes that there is one universal code that is unalterable which "represents the ultimate values of all people. ${ }^{303}$ This belief opposes the principles of cultural relativism, which advocates that there is no universal code of morality, but instead, that each culture defines its own morals and no one else has the right to intervene.

Like most traditional practices, female genital mutilation is the epitome "of a society's beliefs and values that outsiders of a culture cannot always understand." "305 However, acknowledging the social context does not undervalue the criticism of the practice. ${ }^{306}$ Cultural relativists "argue that individual sovereignties have the right to do what they want without the threat of interference," but this notion should be disregarded when it comes to fundamental human rights. ${ }^{307}$ Although, societies "should be left to their own standards of morality," even if "others find those standards repugnant," the international community must step in "when those standards violate universal human rights.", "Like the ancient Chinese practice of repeatedly breaking and binding women's feet .... [the] brutality of [female genital mutilation] speaks louder than any [ethical relativist's] argument.",309

The international community desires respect for cultural differences. ${ }^{310}$ According to The International Covenant on Economic, Social and Cultural Rights, all persons have the freedom to pursue their economic, social, and cultural development. ${ }^{311}$ However, this cannot be achieved at the expense of equality or "the enjoyment of the highest attainable standard of physical and mental health.",312 "Throughout history, the global community has not tolerated violations of fundamental human rights.",313 The idea of tolerating female genital mutilation, a human rights violation, to continue freely "be-

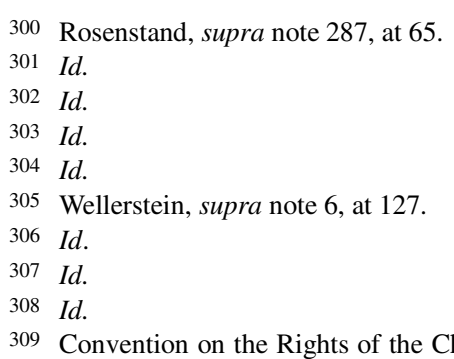
49, at 167, U.N. Doc. A/44/736/Annex (Sept. 2, 1990). Reprinted in 28 I.L.M. 1448, 1448

310 See, e.g., Declaration on the Elimination of All Forms of Intolerance and of Discrimination Based on Religion or Belief, G.A. Res. 36/55, U.N. Doc. A/36/684 (Nov. 25, 1981), 21 I.L.M. 205 (1982).

311 Liu, supra note 53, at 84 (citing International Covenant on Economic Social and Cultural Rights, G.A. Res. 2200A (XXI), Annex, 21 U.N. GAOR Supp. (No. 16) at 49, U.N. Doc. A/6316/Annex (Jan. 3, 1976)).

312 Id. (quoting 993 U.N.T.S. 3, 6 I.L.M. 360 (1967), adopted by General Assembly of the United Nations on Dec. 16, 1966 (Annex to G.A. Res. 2200), entered into force Jan. 2, 1976).

313 Wellerstein, supra note 6, at 127. 
cause it is an untouchable 'cultural' issue, [goes against] the lessons the international community has learned from past experiences.",314

When the world discovered inhumanities occurring in the concentration camps of Nazi Germany, the international community intervened to free the victims. ${ }^{315}$ After the world discovered "the Cambodian killing fields after the Vietnam War," it stepped in, and the international community intervened to put a stop to apartheid in South Africa and racial persecution in Bosnia. ${ }^{316}$ The international community has intervened in cultural issues when human rights are in danger. ${ }^{317}$

Numerous "human rights documents have codified this universalist belief 'that there are human rights so fundamental to every human being that they transcend all societal, political and religious constraints.",318 For instance, "the Universal Declaration openly states that '[n]o one shall be subjected to torture or cruel, inhuman or degrading treatment or punishment.' „319 “Permanently disfiguring a woman's body, without anesthesia, which often causes serious infection or death, is nothing less than the worst kind of torture." "320 "It is the kind of torture that stays with a mutilated woman for the rest of her life, in body and mind, as a daily reminder of the 'crime' she committed in being born as a female., 321

\section{B. International Resolutions Against Female Genital Mutilation}

Female genital mutilation is a concern for lawmakers worldwide. ${ }^{322} \mathrm{~A}$ study of the present-day status of female genital mutilation in Western countries shows that wherever immigrants from Africa and the Middle East settle, they bring the practice with them. ${ }^{323}$ Countries such as Great Britain, ${ }^{324}$ Sweden, ${ }^{325}$ and France ${ }^{326}$ have enacted laws criminalizing female ge-

318 Wellerstein, supra note 6 at 128 (quoting Robin M. Maher, Female Genital Mutilation: The Modern Day Struggle to Eradicate a Torturous Right of Passage, HuM. RTS. MAG., 1996, http://www.abanet.org/irr/hr/fgm.html).

319 Universal Declaration of Human Rights, supra note 295, at art. 5.

320 Id. at 128.

321 Id.

322 Coello, supra note 41, at 216.

323 Hosken, supra note 3 , at 27.

324 The practice was criminalized by the Prohibition of Female Genital Circumcision Act of 1985 , which states that anyone who performs, aids, abets, counsels or procures female genital mutilation on another person will be subjected to fines or imprisonment. Prohibition of Female Circumcision Act, 1985, ch. 38, § 1 (Eng.); Donu Kogbara, et al., Harley St. Surgeon Agreed to Perform Female Circumcision, SUNDAY TIMES, Oct. 18, 1992.

325 In Sweden, all forms of female genital mutilation are illegal. Toubia, supra note 46, at 715. The Swedish government granted residence permits to two families based on humanitarian reasons. Coello, supra note 41 , at 225 . 
nital mutilation. ${ }^{327}$ In Canada, the practice is criminalized under child abuse legislation in the Criminal Code $;{ }^{328}$ however, there has been a movement to pass specific legislation criminalizing female genital mutilation. ${ }^{329}$ Some African nations have also taken steps to eliminate female genital mutilation. ${ }^{330}$ In Kenya, there is a nationwide ban on the procedure. ${ }^{331}$ While female genital mutilation has not been entirely banned in Egypt, it has been prohibited in government clinics. ${ }^{332}$

In France, parents have been prosecuted for submitting their daughters to female genital mutilation. ${ }^{333}$ The French community has taken a strong stance against the practice of female genital mutilation, which sends immigrants who adhere to the practice a message that female genital mutilation will not be tolerated on French soil. ${ }^{334}$ A French jury sentenced a Malian woman, who was found guilty of performing female genital mutilation on seventeen girls, to five years in prison. ${ }^{335}$ A French court sentenced a Gambian mother to a jail sentence of one year. ${ }^{336}$ Also, a Malian man was sentenced to one month in a French prison when his two wives testified that he had forced them to have their daughters undergo the procedure. ${ }^{33}$

However, when the practice is performed in the name of tradition, the French have been lenient in punishing female genital mutilation. ${ }^{338}$ In a case against two Malian mothers who subjected their three-year-old daughters to female genital mutilation, the jury was lenient and gave each woman a five-year suspended sentence. ${ }^{339}$ Both women claimed that they were ignorant as to the French law prohibiting the practice. ${ }^{340}$ They stated that they submitted their daughters to the practice because they themselves had

326 Rone Tempest, Ancient Traditions v. the Law, L.A. TIMES, Feb. 18, 1993.

327 Id.

328 Hughes, supra note 1, at 335 (citing Ban Urged for Genital Mutilation, CALGARY HeRALD (Canada), Mar. 8, 1994, at A7).

329 The movement was prompted by the fact that many African immigrants and refugees were requesting the procedure. Hughes, supra note 1, at 370 n.75 (citing Nancy I. Kellner, Under the Knife: Female Genital Mutilation as Child Abuse, 14 J. Juv. L. 118, 122 (1993)).

330 Id. African countries that have enacted legislation prohibiting female genital mutilation include: Cameroon, Dijibouti, Egypt, Kenya, Ghana, and the Sudan. Id.

331 Female Circumcision: Because It's Always Been Done, The Economist, Sept. 18, 1982, at 42. Kenya's President Moi ordered police to charge anyone who performed female genital mutilation with murder. Id. Health workers were also prohibited from becoming involved with any form of female genital mutilation. Id.

332 Deborah Pugh, Egypt Urged to End Genital Mutilation, GuARDIAN, Mar. 28, 1994, at 8.

333 Tempest, supra note 326.

334 Id.

335 Id.

336 Id.

337 Id.

338 Tempest, supra note 326.

339 Id.

340 Id. 
undergone the procedure, as had their ancestors. ${ }^{341}$ Thus, because the procedure was performed as part of a cultural tradition, the French jury was hesitant in giving a severe sentence.

Many international organizations have been actively advocating the eradication of female genital mutilation. ${ }^{342}$ The American Medical Association ("AMA") has worked with other major international bodies, including the World Health Organization ("WHO"), the World Medical Organization ("WMO"), other interested national medical societies, UNICEF, and the International Federation of Gynecology and Obstetrics in challenging all forms of female genital mutilation, promoting awareness of the practice among public health care workers, and educating health care professionals around the world about the implications associated with the custom and how to best treat survivors. ${ }^{343}$ The AMA has advised lawmakers to adopt legislation that will eliminate the performance of female genital mutilation and all medically unnecessary modifications of the female genitalia. ${ }^{344}$ Promoting international awareness of female genital mutilation is an important step in eradicating the tradition.

The purpose in limiting the practice of female genital mutilation is to protect valuable human rights. The international community is committed to promoting the preservation of human rights globally. ${ }^{345}$ The United Nations Charter specifically states that its purpose is " $[\mathrm{t}] \mathrm{o}$ achieve international co-operation . . . in promoting and encouraging respect for human rights and for fundamental freedoms for all without distinction as to race, sex, language, or religion." "346 According to Articles 55 and 56 of the Charter, all signatories pledge "to take joint and separate action in cooperation with the Organization for the achievement of the purposes" ${ }^{, 34}$ of the United Nations, including the promotion of "a universal respect for, and observance of, human rights and fundamental freedoms for all."

The meaning of the term "human rights" was expanded with the enactment of the Universal Declaration of Human Rights. This document defines human rights as the inherent dignity of every human person that is

341 Id.

342 These organizations include: Sudan Family Planning Association, Ahfad University College for Women, Obstetrics and Gynecological Society, Saluker Badri Scientific Association for Women's Studies, World Health Organization, UNICEF, the Swedish Radda Baren, Swedish Housewives Association, and the Norwegian Action Group. Id.

343 AMA Calls for Legislation to Eliminate Female Genital Mutilation, PR NEWSWIRE, Dec. 7, 1994.

344 Id.

345 Jessica A. Plat, Note, Female Circumcision: Religious Practice v. Human Rights Violation, 3 RutGers J.L. \& RELIGION 1, 44 (2002).

346 U.N. Charter art. 1, para. 3.

347 U.N. Charter art. 56.

348 U.N. Charter art. 55, para. c. 
inalienable and imprescriptible. ${ }^{349}$ Moreover, human rights are universal, acquired at birth by "all members of the human family whatever the political, jurisdictional or international status of the country or territory to which a person belongs." ${ }^{, 350}$ The Declaration acknowledges certain limitations on the exercise of human rights "solely for the purpose of securing due recognition and respect for the rights of others and of meeting the just requirements of morality, public order and the general welfare in a democratic society." 351 Although the Universal Declaration of Human Rights does not specifically address human rights violations and cultural and religious practices, including the practice of female genital mutilation, the declaration has used conventions and human rights legislation to support the eradication of female genital mutilation in the international arena.

For example, the Convention on the Elimination of All Forms of Discrimination Against Women ("Women's Convention") proposes to eliminate discrimination against women by creating equality between men and women, and by guaranteeing the freedom of women's rights universally. ${ }^{353}$ The Women's Convention advocates human rights for women where "the enjoyment of civil and political rights is indivisible from the realization of economic, social and cultural rights.",354 Article 5(a) requires member states "to modify the social and cultural patterns of conduct . . . with a view to achieving the elimination of prejudices and customary and all other practices which are based on the idea of the inferiority or the superiority of either of the sexes or on stereotyped roles for men and women., 355

\section{Learning from the International Community}

The international community has chosen to deal with the problem of female genital mutilation by creating laws that criminalize the practice when it is performed on young girls and women. Unlike the United States, which takes a child abuse perspective by only criminalizing female genital mutilation when it is performed on girls under the age of eighteen, other

\footnotetext{
349 The United Nations Blue Book Series, The United Nations and Human Rights, at 524, U.N. Sales No. E.95.I.21 (1995).

$350 I d$. at 25 .

351 Id.

352 See The International Covenant on Civil and Political Rights, G.A. Res. 2200A (XXI), 21 U.N. GAOR Supp. (No. 16) at 52, U.N. Doc. A/6316 (March 23, 1976); The Convention of the Elimination of All Forms of Discrimination Against Women, GA Res. 34/180, 34 U.N. GAOR Supp. (No. 46) at 193, U.N. Doc. A/34/46 (Sept. 3, 1981) [hereinafter Women's Convention]; The Committee on the Elimination of Discrimination Against Women, General Recommendation No. 19, Violence Against Women (Eleventh session, 1992), U.N. Doc. A/47/38 at 1 (1993); The United Nations Convention on the Rights of the Child, G.A. Res. 44/25, Annex, U.N. GAOR Supp. (No. 49) at 167, U.N. Doc. A/44/49 (Sept. 2, 1990).

353 Women's Convention, supra note 352.

354 Louis Henkin Et AL., HumAn Rights 274, 360 (1999).

355 Women's Convention, supra note 352, at art. 5., para. a.
} 
countries have chosen to expand the law and criminalize female genital mutilation when it is performed on women of any age. It focuses not only on the implications of female genital mutilation from a medical perspective, but also from a societal perspective.

Many international players have become involved in criminalizing female genital mutilation because the practice primarily serves to reinforce the subordination of women. It also attacks the physical and moral integrity of women and young girls. Female genital mutilation is a means of controlling a woman's sexual behavior. It implies that women cannot be trusted to preserve their own chastity, and thus, to be "marriage material," they must be subjected to this barbaric practice to ensure their chastity.

The United States should follow in the international community's footsteps. The legislation banning female genital mutilation should be expanded to include women, in addition to children. As a nation that prides itself on social equality, the United States has a great interest in criminalizing this practice, not only as a form of child abuse, but also as a matter of women's rights. As a matter of public policy, women have the right to be treated equally with men.

Supporters have tried to compare female genital mutilation to male circumcision, but the performance and benefits associated with the two practices widely differ. Male circumcision is performed as a matter of hygiene, providing the man with a variety of health benefits. These benefits include: easier hygiene, ${ }^{356}$ decreased risk of urinary tract infection, ${ }^{357}$ prevention of penile problems, ${ }^{358}$ decreased risk of penile cancer, ${ }^{359}$ and decreased risk of sexually transmitted diseases. ${ }^{360}$ Female genital mutilation has no positive health benefits and serves to subordinate the woman in society by abating women's sexual desires, ${ }^{361}$ which makes women vulnerable to male domination. ${ }^{362}$ Public policy also supports eliminating this practice to protect the health, safety, and welfare of women.

If we view female genital mutilation as a form of child abuse, then certainly it must follow that it is also a form of domestic abuse. Husbands who require their wives to be subjected to this procedure should be guilty of

356 Circumcision facilitates the washing of the penis. See MaYo CliniC STAFF, MaYoClinic.Com, Circumcision For Baby Boys: WeIghing the Pros And Cons (Mar. 1, 2008), http://www.mayoclinic.com/health/circumcision/PR00040.

357 The risk of urinary tract infections is ten times more common in uncircumcised baby boys. Id.

358 The foreskin of an uncircumcised penis may be difficult or impossible to pull back, which may lead to inflammation of the head of the penis. Id.

359 Cancer of the penis is less common in circumcised men. Id.

360 Id. Circumcised men have a lower risk of sexually transmitted diseases including HIV, the virus that causes AIDS and human papillomavirus (HPV), which causes genital warts. Id.

361 Eugene Anne Gifford, The Courage to Blaspheme: Confronting Barriers to Resisting Female Genital Mutilation, 4 UCLA WoMEN's L.J. 329, 345 (1994).

362 Id. 
domestic violence. However, under the current federal law they would not be subject to legal repercussions, and they would escape through the cracks of the legal system since current law criminalizes female genital mutilation only when performed on girls under the age of eighteen. Therefore, to fully protect against the consequences associated with this practice, the law should be expanded to include women of all ages.

The international arena has taken more efficient steps in eradicating the practice by viewing its negative impact from a human rights perspective. Globally, we as human beings have a duty to protect the basic rights of other human beings. These fundamental rights include: the right to be free from bodily invasion ${ }^{363}$ and torture, ${ }^{364}$ the right to health; ${ }^{365}$ the right to personal dignity; ${ }^{366}$ the right to be free from discrimination; ${ }^{367}$ and the right to not be subjected to cruel, inhuman, or degrading treatment. ${ }^{368}$ Consequently, this includes the right to preserve one's bodily organs. Although some women encourage the practice as a rite of passage, many of the women subjected are forced to undergo the procedure under protest. It is unconscionable to impose such a practice on women. Thus, by viewing it as a violation of human rights, governments can take action against it not only from a child abuse perspective but also from a woman's perspective.

\section{CONCLUSION}

The United States must take action and expand the current law banning female genital mutilation to include adult women to show its concern for women, as well as children. The government has a valid interest in protecting the health, safety, and welfare of adult women. It is imperative that female genital mutilation, a heinous act, not be tolerated no matter the age of the victim. As a nation, we must take a strong stance against this practice, along with others in the international community.

In addition, the law currently passes constitutional muster and expanding it to include adult women would not change its constitutional validity. Like practices such as polygamy, which the government has banned, female genital mutilation is harmful to society in that it provides social inequality between men and women.

363 Wellerstein, supra note 6, at 114 (citing Hope Lewis, Between Irua and "Female Genital Mutilation": Feminist Human Rights Discourse and the Cultural Divide, 8 HARv. Hum. RTS. J. 1, 6, 1415 (1995)).

364 Id.

365 Universal Declaration of Human Rights, supra note 295, at art. 5.

366 Id.

367 Id. at art. 1; International Covenant on Civil and Political Rights, Dec. 16, 1966, art. 9, 999 U.N.T.S. 171, 172 (entered into force Mar. 23, 1976).

368 Universal Declaration of Human Rights, supra note 295, at art. 5. 
The government should give great weight to the protection of the health, safety, and welfare of its citizens and prohibit female genital mutilation for everyone, regardless of age. The United States should look to the international community and recognize female genital mutilation as a violation of human rights. Such violation must be severely punished, not only when it is conducted on little girls, but also when it is conducted on adult women. The female subordination that this practice promotes is intolerable. Allowing the persistence of this practice is a step backward in the feminist movement that so many women have fought for.

Furthermore, the United States must take action in educating supporters of female genital mutilation as to the consequences associated with the practice. Simply criminalizing the performance of female genital mutilation on adult women will not do. It is imperative that the government provide educational materials informing supporters of the serious implications that result from the practice of female genital mutilation. But education should not be limited to supporters living in the United States. Because this is a problem of international concern, the United States should join other countries that are working to eliminate the practice by promoting international awareness about the problem. In addition, these countries should reach out to countries where mutilation is protected and educate them as to the physical and societal harm that the tradition causes.

Female genital mutilation is a dangerous practice with great physical, psychological, and social implications for women. Its effects are so detrimental that the practice should be banned completely. The idea is not to make the rest of the world conform to western views. Rather, the goal is to ban a cultural practice that has no real benefits to preserve the health, safety, and welfare of all the world's citizens, including those citizens who are women. 